\title{
Assessment of the Indoor Odour Impact in a Naturally Ventilated Room
}

\author{
Lidia Eusebio, Marco Derudi, Laura Capelli, Giuseppe Nano and Selena Sironi * \\ Politecnico di Milano, Dipartimento di Chimica, Materiali e Ingegneria Chimica "G. Natta", \\ P.za Leonardo da Vinci 32, 20133 Milano, Italy; lidia.eusebio@polimi.it (L.E.); marco.derudi@polimi.it (M.D.); \\ laura.capelli@polimi.it (L.C.); giuseppe.nano@polimi.it (G.N.) \\ * Correspondence: selena.sironi@polimi.it; Tel.: +39-02-2399-3292 \\ Academic Editor: W. Rudolf Seitz
}

Received: 31 January 2017; Accepted: 31 March 2017; Published: 5 April 2017

\begin{abstract}
Indoor air quality influences people's lives, potentially affecting their health and comfort. Nowadays, ventilation is the only technique commonly used for regulating indoor air quality. $\mathrm{CO}_{2}$ is the reference species considered in order to calculate the air exchange rates of indoor environments. Indeed, regarding air quality, the presence of pleasant or unpleasant odours can strongly influence the environmental comfort. In this paper, a case study of indoor air quality monitoring is reported. The indoor field tests were conducted measuring both $\mathrm{CO}_{2}$ concentration, using a photoacoustic multi-gas analyzer, and odour trends, using an electronic nose, in order to analyze and compare the information acquired. The indoor air monitoring campaign was run for a period of 20 working days into a university room. The work was focused on the determination of both $\mathrm{CO}_{2}$ and odour emission factors (OEF) emitted by the human activity and on the evaluation of the odour impact in a naturally ventilated room. The results highlighted that an air monitoring and recycling system based only on $\mathrm{CO}_{2}$ concentration and temperature measurements might be insufficient to ensure a good indoor air quality, whereas its performances could be improved by integrating the existing systems with an electronic nose for odour detection.
\end{abstract}

Keywords: odour monitoring; emission factors; indoor air quality; naturally-ventilated rooms; $\mathrm{CO}_{2} ;$ modeling

\section{Introduction}

Over the last few decades, since the first electronic noses were realized in the 1980s, several studies aimed to investigate some relevant applications of electronic noses for the monitoring of different volatile or semi-volatile pollutants and odour sources.

Nowadays, electronic noses are considered the most promising tools for odour monitoring [1] and the use of these instruments in different sectors has increased [2,3]. In more detail, the research areas in which the application of the electronic noses have been more lively are:

- The food industry, involving several uses, such as process monitoring, freshness evaluation, shelf-life investigation, and authenticity assessment [4-10]. In Italy, the development of electronic noses for the food industry is very active and focused on freshness evaluation, microbial evaluation and authenticity assessment [11-19];

- The healthcare sector that comprehends cosmetics, pharmaceuticals [20,21] and diagnostic [22-26]. In Italy, the research of the electronic nose for the healthcare field is particularly developed in the diagnostic area. Several studies have dealt with issues relating the development of electronic noses as tools for the diagnosis of different cancer types (such as those involving lungs, bladders, and prostates) and the identification of different bacterial infections [27-32]; 
- The environmental sector [33-40]; a recent review [36] on the application of electronic noses in environmental monitoring considered four main research activities: the analysis of parameters related to air quality; the analysis of parameters related to water quality; the process control; and the verification of efficiency of odour control systems. In Italy, the research related to the development and application of the e-nose in the environmental field is very active [41-52]. Issues mainly dealt with:

1. The identification of a method to evaluate the performances of the electronic nose. This topic is particularly interesting internationally because of the recent formation of a technical committee dedicated to the definition of specific regulations of the electronic noses for their standardization;

2. The analysis of parameters related to air quality;

3. The analysis of parameters related to water quality;

4. The process control, as well as the verification of the efficiency of odour control systems.

- The indoor applications [53-61] are focused on the detection of the odour compounds that can worsen the air quality and possibly pose some safety problems. Only few Italian studies [62-65] focus the attention on the indoor air quality (IAQ) monitoring and safety.

The application of the electronic nose in the indoor monitoring, as a tool for the pollution assessment and control, has drawn an increasing interest in the last years. This is confirmed by the increase of the international studies related to the application of these instruments in indoor monitoring $[53-56,59,62,63]$. This interest is due to a growing awareness of the indoor air quality of environments where people live and work [64].

The main methods used to monitor and manage indoor environments are generally based on measurements of some physical and chemical parameters [64]. The $\mathrm{CO}_{2}$ concentration is often measured and used as a typical marker for the assessment of bad air quality caused by humans $[54,55]$ because both $\mathrm{CO}_{2}$ and emissions of bio-effluents (such as some VOCs-Volatile Organic Compounds) are directly related to human metabolism and activities. Comfort criteria, considered in the American Society of Heating, Refrigerating and Air-Conditioning Engineers/American National Standards Institute ANSI/ASHRAE Standard 62-2001 [66], are satisfied if the ventilation of a room guarantees a difference between the indoor and the outdoor $\mathrm{CO}_{2}$ concentration below $700 \mathrm{ppm}$ [55]. Furthermore, other standards and guidelines, like the European Standards EN 13779 [67], EN 15251 [68] and the German Standard DIN 1946-2 [69], refer to the $\mathrm{CO}_{2}$ concentration to evaluate the ventilation effectiveness and the indoor air quality; these standards advise to keep indoor $\mathrm{CO}_{2}$ concentration below $1000 \mathrm{ppm}[54,55]$. However, it was demonstrated that the monitoring of solely temperature, humidity and $\mathrm{CO}_{2}$ concentration could be not exhaustive in order to evaluate the indoor air quality [64]. Indeed, the presence of chemical pollutants and their accumulation with time into indoor environments can cause Building Related Illness (BRI) and Sick Building Syndrome (SBS) disease, especially in buildings with a limited natural ventilation [55] and without a mechanically-controlled ventilation [62].

The indoor air quality is influenced by different factors, such as people's activities, high occupancy, accidental release of potentially harmful substances or pollutants that come in from external environments, which could change the indoor air composition and affect the living conditions. As it was estimated that about $40 \%$ of primary energy in Europe is consumed in buildings to ensure better indoor conditions for occupants, especially for heating, cooling and ventilation [54], a proper IAQ monitoring can lead to an improved life quality decreasing the causes of possible illnesses and defining more efficient ventilation strategies.

Generally, the indoor air quality evaluation is tightly related to olfactory perceptions. Annoying or pungent odours can influence people perception negatively. The standardized method for odour assessment is a sensorial technique called dynamic olfactometry, which uses a human sensory panel. Dynamic olfactometric tests are generally time-consuming and cost-intensive, thus making them 
not appropriate for a continuous monitoring $[54,56]$. These disadvantages could be overcome by an instrumental assessment involving the use of an electronic nose.

An overview of relevant international research about the indoor air quality monitoring is summarized in Table 1, which, besides authors and year, reports the application area of the electronic nose and the sensor type adopted.

Table 1. International studies focused on the use of e-noses for indoor air quality monitoring.

\begin{tabular}{|c|c|c|c|}
\hline Authors (Year) & Application Area & Sensor Type ${ }^{a}$ & Reference Number \\
\hline Arnold et al. (2002) & $\begin{array}{l}\text { Use the electronic nose in the indoor environment to detect the } \\
\text { early fires }\end{array}$ & MOS & 53 \\
\hline Bitter et al. (2010) & $\begin{array}{l}\text { Estimation of odour intensity of indoor air pollutants from } \\
\text { building materials }\end{array}$ & MOS & 56 \\
\hline Wolfrum et al. (2006) & $\begin{array}{l}\text { Developing of a cheap device for detection, differentiation and } \\
\text { quantification of volatile organic compounds at } \\
\text { sub-parts-per-million concentration levels }\end{array}$ & MOS & 57 \\
\hline Kuske et al. (2005) & $\begin{array}{l}\text { Review about the detection of fungal contamination in indoor } \\
\text { environments with electronic nose }\end{array}$ & $\begin{array}{l}\text { CP } \\
\text { MOS }\end{array}$ & 58 \\
\hline Tian et al. (2012) & $\begin{array}{l}\text { Application of the electronic nose in the monitoring of in-car air } \\
\text { quality }\end{array}$ & MOS & 59 \\
\hline
\end{tabular}

The following three studies present the Italian research on the indoor air quality monitoring.

The study of Burresi et al. presents a $\mathrm{CO}$ commercial sensor for indoor monitoring with the purpose to develop a portable device with both a small size and a low power consumption (around $250 \mathrm{~mW}$ ) [62].

Zampolli et al. present a work about the environmental safety in indoor monitoring using an electronic nose able to quantify toxic compounds coming from combustion processes (i.e., $\mathrm{CO}$ and $\mathrm{NO}_{2}$ ) in spite of the presence of interfering species like VOCs and humidity [63].

Sironi et al. [64] present the preliminary results of an indoor monitoring campaign performed in a naturally ventilated room; in particular, $\mathrm{CO}_{2}$ measurements are compared with the results obtained from an electronic nose. This study shows the importance to include the odours monitoring in the procedure to evaluate the indoor air quality. Joining $\mathrm{CO}_{2}$ measurements with the information obtained from the electronic nose would allow for optimizing a correct ventilation of the indoor environment.

Nozza et al. [65] present an interesting work on the application of the electronic nose for monitoring the indoor air quality in a room where different kinds of flueless fireplaces were posed. The study presents not only the monitoring of the common pollutants (i.e., $\mathrm{CO}, \mathrm{CO}_{2}$, $\mathrm{NOx}$, and VOCs) but also the odour emission factors of flueless fireplaces analyzed by separating the contribution of the different operating phases (ignition, shutdown).

The aim of this paper is to present a case study of indoor monitoring in a typical study room naturally ventilated not provided by a mechanical ventilation system. The indoor air monitoring was performed using both an electronic nose to monitor the odours and a photoacustic multi-gas analyzer to detect the $\mathrm{CO}_{2}$ over the time for a period of 20 working days. The focus of the work is on the determination of both $\mathrm{CO}_{2}$ and odour emission factors (OEF) emitted by the human activity and on the evaluation of the odour impact in a naturally ventilated room. This was done analogously with another study on OEF [65], although the sources analyzed in the present work are multiple and not stationary. 


\section{Materials and Methods}

\subsection{Analytical Equipment}

An e-nose for indoor odour monitoring and a photoacoustic multi-gas instrument for the $\mathrm{CO}_{2}$ detection were used for the experimental measurements.

The electronic nose used is called EOS 101, provided by Sacmi S.C., Imola, Italy. It is a simplified electronic nose, cheap and small-sized, designed specifically for indoor environments for the determination of the presence/absence of odours; a scheme of EOS 101 is reported in Figure 1.

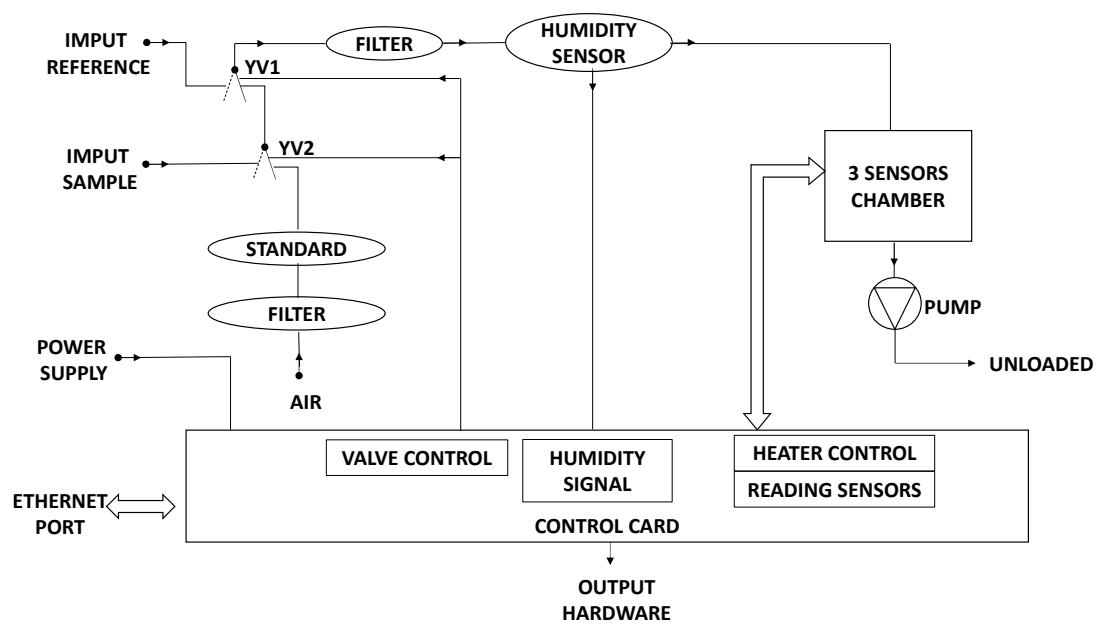

Figure 1. EOS 101 scheme.

The EOS 101 is equipped with three Methal Oxide Sensors (MOS) sensors with active film consisting of a Tin oxide thin layer and Tin oxide catalyzed with molybdenum. The sensors are calibrated with a reference substance-n-butanol [65]. The EOS 101 e-nose has two inlets. One inlet is used for the reference air to set the baseline, while the other one to collect the air samples to be analyzed. The reference air was made using a filtration system. The sensor responses are compensated by a software to correct the influence of humidity variations; this is considered enough for indoor applications, characterized generally by low humidity variations.

The EOS 101 has been developed in order to determine the presence/absence of odours, without classifying their quality. This means that the instrument is not designed to classify the analyzed air [64]. EOS 101 continuously analyzes the indoor air and the instantaneous output signal produced by each sensor is expressed in EOS Units $\left(E U_{i}\right)$, which are calculated as follows [65]:

$$
E U_{i}=a_{i} *\left(\frac{R_{i}}{R_{s t d, i}}\right)^{b_{i}}
$$

where $R_{i}$ is the resistance value, $R_{s t d, i}$ is the standard resistance value, and $a_{i}$ and $b_{i}$ are characteristic coefficients depending on the sensor type. The so-defined EOS Units can be correlated with the odour concentration (in odour units for cubic meters- $\mathrm{ou}_{\mathrm{E}} / \mathrm{m}^{3}$ ) [65].

The $\mathrm{CO}_{2}$ concentration was indeed monitored with an Airnova 1312 photoacoustic multi-gas monitoring system (Limena, Italy). Its measurement principle is based on the photoacoustic infra-red detection method. Some optical filters (up to 5) can be installed in the 1312 filter carousel so that it can selectively measure the concentration of up to 5 gaseous species, such as $\mathrm{CO}_{2}, \mathrm{CO}$, water vapor, etc. in any air sample. Its detection limit is gas-dependent, but typically is in the ppb region. Reliability of measurement results can be ensured by self-tests that are regularly performed by the instrument. Accuracy is guaranteed by compensating any measurement for temperature fluctuations, water vapor and/or other species interferences. 
The gas species detection is ensured by the fact that the light transmitted by the optical filter is selectively absorbed by the gas being monitored, causing the temperature of the gas to increase. Because the light is pulsating, the gas temperature increases and decreases, causing an equivalent increase and decrease in the pressure of the gas (an acoustic signal) in the closed cell. Two microphones mounted in the cell wall measure this acoustic signal, which is directly proportional to the concentration of the monitored gas present in the cell.

\subsection{Case Study}

A university study room, not equipped with a mechanical ventilation system, was monitored. Generally, the room taken into account was used for both studying and taking lunch, especially for the time between 12:30 p.m. and 2:30 p.m. (Figure 2).

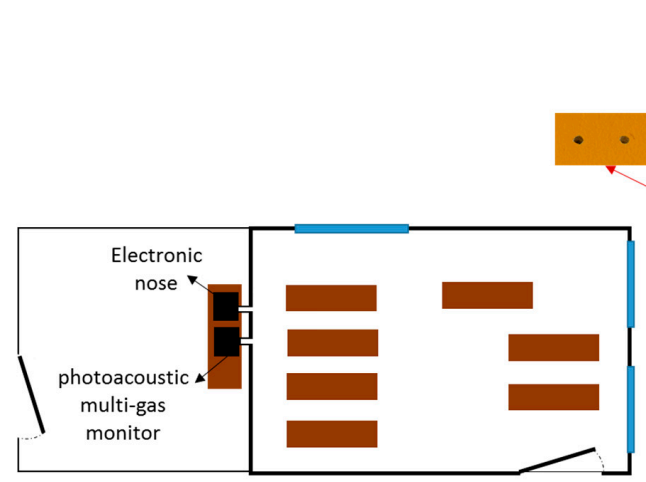

(a)

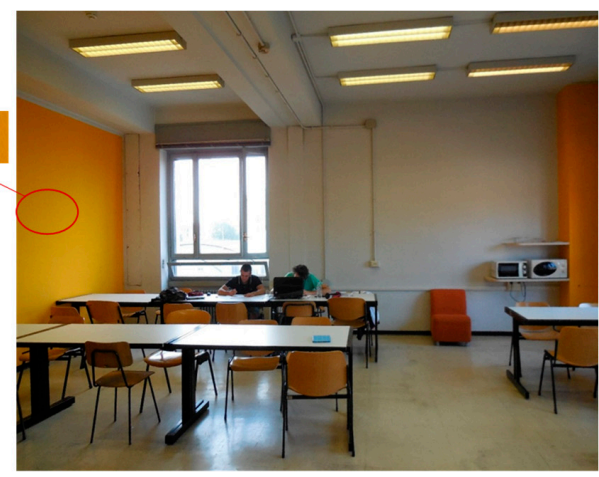

(b)

Figure 2. The university study room monitored: Scheme of the study room and the link with monitoring system (a); picture of the study room (b).

During the experimental campaign, both the Airnova 1312 photoacoustic multi-gas monitor system and the electronic nose were interfaced with this naturally ventilated chamber thanks to some sampling points placed on the test chamber wall. The instruments were placed in an adjacent room and connected to the study room using a couple of Teflon pipes through sampling holes realized into the wall. From these pipes, air samples of the study room were continuously collected and analyzed both by EOS 101 and the photoacoustic $\mathrm{CO}_{2}$ analyzer.

The number of occupants of the investigated room was counted and recorded almost every hour, as well as the activity that was taking place (study and/or lunch) was registered.

The EOS 101 data were processed based on the instantaneous output signal EOS Units $\left(E_{i}\right)$ acquired. An average of the EOS Units of the three sensors (EU) was used to calculate specific odour emission factors (OEFs) $\left(\mathrm{ou}_{\mathrm{E}} / \mathrm{h}\right)$.

With the aim of assessing the characteristic odour impact of the students' activities, specific odour emission factors $(\mathrm{OEFs})\left(\mathrm{ou}_{\mathrm{E}} / \mathrm{h}\right)$ were evaluated in terms of odour emitted as a function of time from the room occupants.

In order to determine the OEF relevant to the different activities, an odour material balance on the investigated room was set, according to the following expression:

$$
V * \frac{d E U}{d t}=Q * E U_{I N}-Q * E U+O E F
$$

where $V\left(\mathrm{~m}^{3}\right)$ is the room volume (i.e., $\left.182 \mathrm{~m}^{3}\right), Q\left(\mathrm{~m}^{3} / \mathrm{h}\right)$ is the estimated volumetric air flow rate which ensure the natural ventilation of the room, $E U$ (that is roughly proportional to an odour concentration, expressed in $\mathrm{ou}_{\mathrm{E}} / \mathrm{m}^{3}$ ) is the average value of the $E U_{i}$ signals registered by the sensors, and $O E F$ is the odour emission factor $\left(\mathrm{ou}_{\mathrm{E}} / \mathrm{h}\right)$. 
Solving the balance, the specific $\mathrm{OEF}$, considered as an average value for people inside the room $\left(O E F_{n}\right.$, expressed in $\mathrm{ou}_{\mathrm{E}} / \mathrm{h}$ per person), can be estimated as follows:

$$
O E F_{n}=\frac{Q}{n} * \frac{E U_{t}-E U_{t 0} * \exp \left[-\frac{Q}{V} *\left(t-t_{0}\right)\right]}{1-\exp \left[-\frac{Q}{V} *\left(t-t_{0}\right)\right]},
$$

where $n$ is the number of occupants in the investigated room.

Odour Emission Factors (OEFs) are useful tools as they are not only descriptive indicators but also predictive, in agreement with the research performed in an environmental field that brought about the development of OEFs for different kinds of industrial plants such as: wastewater treatment plant (WWTP), Municipal Solid Waste Management Plant (MSWMP), animal rendering plants, and landfills [70-77].

In the case under evaluation, OEFs have been developed in order to assess the odour emissivity due to indoor human activities (i.e., studying and eating). The development of such OEFs is practical as they can be exploited, as an example, in the design of new mechanical ventilation systems for indoor environments.

\section{Results and Discussion}

As previously mentioned, it is useful to properly consider ventilation in order to control the indoor air quality. Among the techniques adopted to perform this kind of evaluations, the one based on the measurement and analysis of the indoor $\mathrm{CO}_{2}$ concentration and trends is the most common approach [78-81]. Even though $\mathrm{CO}_{2}$ is usually not considered as a causal factor in human health responses, it can pose some health problems in the case that its concentration level turns out to be very high inside an environment where people may spend a lot of time. ASHRAE standards [66] consider that acceptable ventilation conditions are achieved if an indoor $\mathrm{CO}_{2}$ level less than $700 \mathrm{ppm}$ above its outdoor concentration is maintained. While this goal can be easily attained in mechanically ventilated rooms, it is not equally easy to keep $\mathrm{CO}_{2}$ and odour levels under control in indoor environments that are naturally ventilated. Natural ventilation is typical of older buildings, such as the one in which the room considered in this study is located, where the ventilation and the IAQ are controlled only by means of the air infiltration through leakages and openings. Into these poorly ventilated and sometimes overcrowded rooms, the situation is even worse during cold seasons, when the desire for thermal comfort and acceptable indoor air quality typically provides conflicting constraints on the ventilation.

To gain some useful information to assess the indoor air quality of the naturally ventilated room previously described, both $\mathrm{CO}_{2}$ concentration and odour trends were monitored over time for a period of 20 working days. Experimental results were analyzed and compared with the predictions of typical models used in ventilation studies and for exposure scenario evaluations [65,82,83].

In particular, a simple model can be defined to estimate the indoor air concentration of one or more target species; such a model can be used also to predict the possible dynamics of a ventilation system, of a variation of the generation rate of the pollutants, etc. Starting from the information related to the emission sources and the corresponding emission rates, which in the case of $\mathrm{CO}_{2}$ are basically identified by the exhaled breath from the occupants involved in sedentary activities, and with reference to the characteristics of the room, in terms of volume, air exchange rates (AER), etc., a one-box model can be defined to dynamically estimate the indoor $\mathrm{CO}_{2}$ concentration trends during the main daily activities as a function of the number of occupants (namely, multiple $\mathrm{CO}_{2}$ and odour sources). A constant release rate of $\mathrm{CO}_{2}$ was assumed from each point-source; considering that the exhaled breath from each occupant contains about $4 \%$ by vol. of $\mathrm{CO}_{2}$, this corresponds to about 22 $\mathrm{g} / \mathrm{h}$ of $\mathrm{CO}_{2}$. A well-mixed environment (WMR) was also considered, so the location of the occupants into the room is not relevant, and $\mathrm{CO}_{2}$, other possible pollutants and odour should be homogeneously distributed within the room $[64,82,83]$. Although the investigated room was only naturally ventilated, 
this simplification could be reasonable because the people movements and their activities improve the mixing between pollutants and indoor air.

Therefore, indoor $\mathrm{CO}_{2}$ concentration can be estimated using a single-compartment mass balance model in which a uniform mixing between pollutants and indoor air is assumed:

$$
C(t)=\left(\frac{n E}{Q}+C_{i n}\right)[1-\exp (-A E R \cdot t)]+C_{0} \cdot \exp (-A E R \cdot t),
$$

where $C(t)$ is the pollutant concentration in the environment $\left(\mathrm{g} / \mathrm{m}^{3}\right.$ or $\left.\mathrm{mg} / \mathrm{m}^{3}\right), C_{0}$ the concentration of the pollutant in the room at the beginning of the considered emission period $\left(\mathrm{g} / \mathrm{m}^{3} \mathrm{or} \mathrm{mg} / \mathrm{m}^{3}\right)$, $C_{i n}$ the concentration of the pollutant in the air exchanged with the adjacent rooms, $n$ the number of occupants, $E$ the emission rate $(\mathrm{g} / \mathrm{h}$ or $\mathrm{mg} / \mathrm{h}), Q$ the air flow rate $\left(\mathrm{m}^{3}\right)$, AER the specific ventilation rate (number of air changes per time unit, defined as the ratio between the ventilation flow rate $Q$ and the room volume $V)\left(\mathrm{h}^{-1}\right)$, and $t$ the time (h).

As the investigated case refers to a naturally ventilated indoor environment, $Q$, and, consequently, $A E R$ are not known parameters, but they must be estimated. For this reason, the experimental data of the unoccupied periods (from about 8:00 p.m. to midnight) were used to determine the value of $A E R$, as shown in the example of Figure 3; the air exchange rate for an unoccupied working period is relatively easier to estimate as the $\mathrm{CO}_{2}$ generation rate is zero and the following expression can be used:

$$
C(t)=C_{i n}+\left(C_{0}-C_{i n}\right) \exp \cdot(-A E R \cdot t)
$$

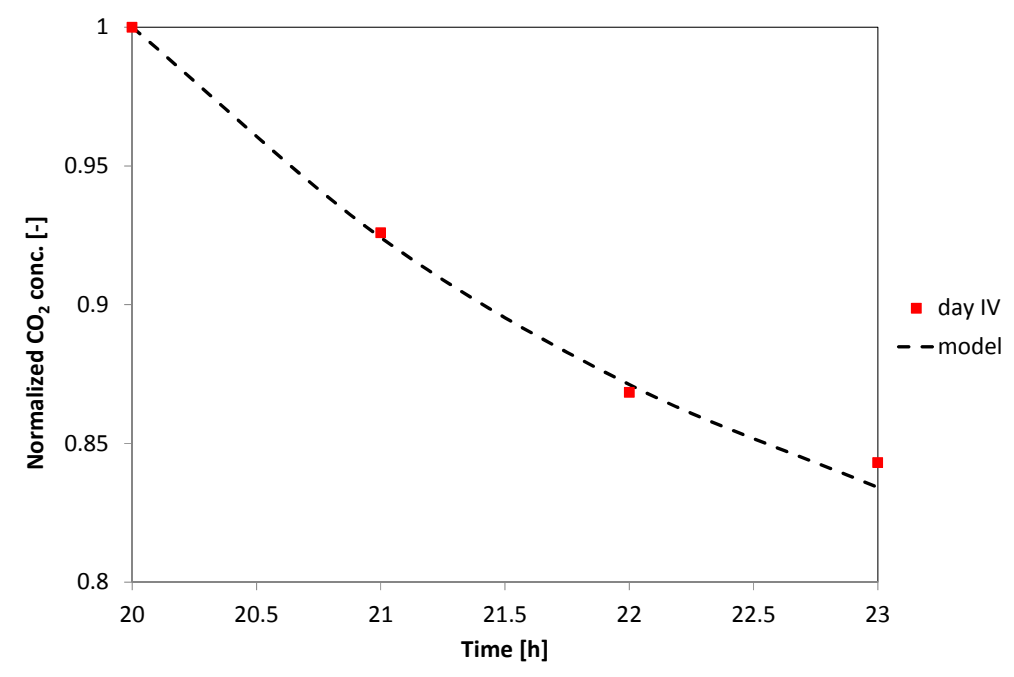

Figure 3. Model fitting of a normalized indoor $\mathrm{CO}_{2}$ concentration trend during an unoccupied period for the estimation of the AER (naturally ventilated room).

Considering the $\mathrm{CO}_{2}$ trends of different days, an average AER value equal to about 0.36 was defined; then, for the occupied periods, when people are present in the room, it was assumed that the daily activities promote both the mixing between air and pollutants and the air exchanges with the external environments; thus, the estimated AER values were increased by a $20 \%$ factor. Referring to the number of occupants detected in the study room, the results of the monitoring campaign are evidenced by the black dashed lines of Figure 4 . These plots report also a comparison between measured (dashed lines) and predicted (solid lines) $\mathrm{CO}_{2}$ trends obtained during two representative working weeks of the experimental campaign. As it can be seen, a reasonable qualitative and quantitative agreement between the $\mathrm{CO}_{2}$ measurements and model predictions was obtained.

These results confirm that $\mathrm{CO}_{2}$ represents a good marker of the human activity in a typical indoor environment; on the other hand, if other possible sources of pollutants and/or volatile chemical 
compounds are present (such as air fresheners, fireplaces, cooking activities, etc.), monitoring only the $\mathrm{CO}_{2}$ trends may not be enough to evaluate in an effective way the indoor air quality. As an example, the odour monitoring and control could be an important issue for air quality evaluation, as evidenced by the experimental results of Figures 5 and 6.

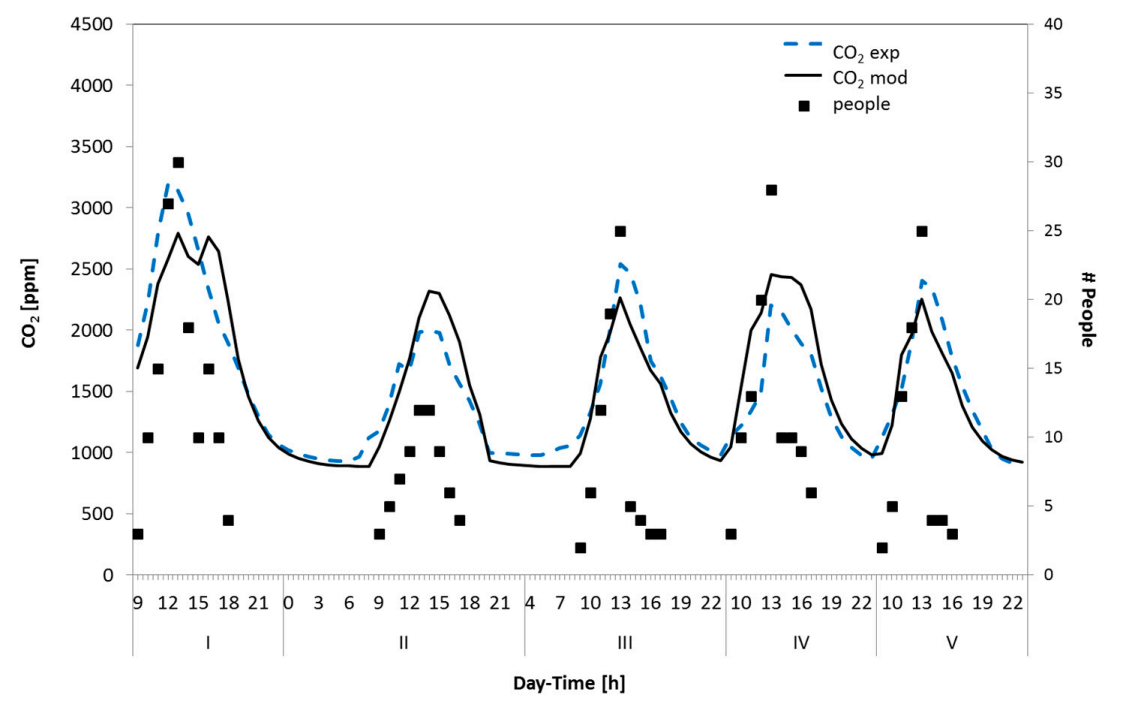

(a)

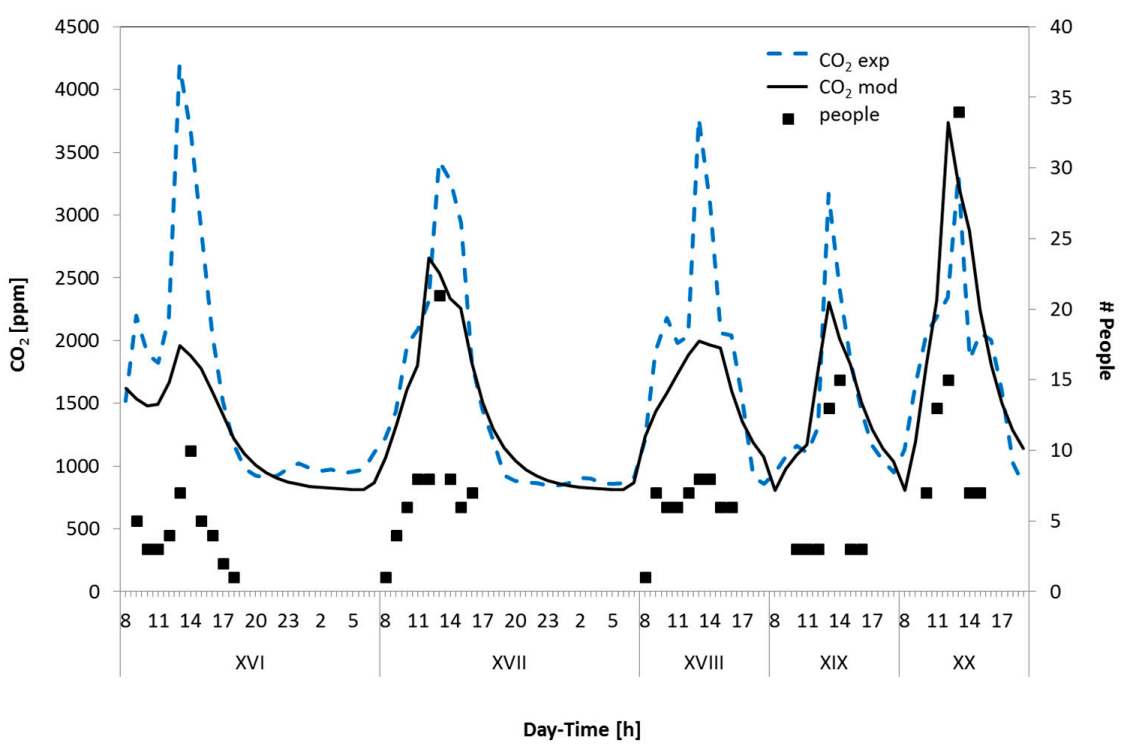

(b)

Figure 4. Experimental and predicted $\mathrm{CO}_{2}$ concentration trends and number of occupants inside the naturally ventilated room investigated. (a) days from I to V; (b) days from XVI to XX.

In particular, Figures 5 and 6 show some extracts of the experimental results by reporting the trends of $\mathrm{EU} / \mathrm{EU}_{0}$, which represent a dimensionless concentration of odour, of the $\mathrm{CO}_{2}$ concentration, the people present in the room, as well as the $\mathrm{OEF}_{n}$ values derived from the experimental data by means of Equation (3). It is possible to observe several typical rise-decay profiles for both odour $\left(\mathrm{EU} / \mathrm{EU}_{0}\right)$ and $\mathrm{CO}_{2}$ concentration, with the peaks that occur concomitantly in the range time between 12:00 p.m. and 2:00 p.m., when the room is more populated, and, as a consequence, a higher $\mathrm{CO}_{2}$ concentration is expected. Moreover, the principal activity during this time is connected to both studying and eating. Students who gather in the room usually use it to study together and have their meals, releasing a smell that is detected by the e-nose. 
It is evident that, on many occasions, the electronic nose and photoacoustic analyzer for the $\mathrm{CO}_{2}$ detection provide complementary results. The electronic nose detects odour molecules (i.e., $\mathrm{EU} / \mathrm{EU}_{0}$ ) and it is unaffected by variations of $\mathrm{CO}_{2}$ concentration, whereas the photoacoustic instrument only detects the $\mathrm{CO}_{2}$ and $\mathrm{CO}$ concentrations. Although the results underline that both instruments show similar qualitative responses, the two instruments give different information. As an example, it is possible to observe during day VII (Figure $5 b$ ) that the $\mathrm{CO}_{2}$ concentration measured was low, showing an almost flat profile because the door of the investigated room was left open to improve the air recirculation. The e-nose has nonetheless detected the presence of odours, with trends similar to those recorded in the other days, with an odour peak during lunchtime (12-14).

During the monitored period, it is also possible to observe in some days (i.e., days II, IV, VIII day of Figure 5, and days XIV to XVI of Figure 6) a peak in the EU/EU $\mathrm{E}_{0}$ signal between 4:00 p.m. and 5:00 p.m. due to the coffee break, whereas the $\mathrm{CO}_{2}$ concentration decreases accordingly with the low number of occupants.

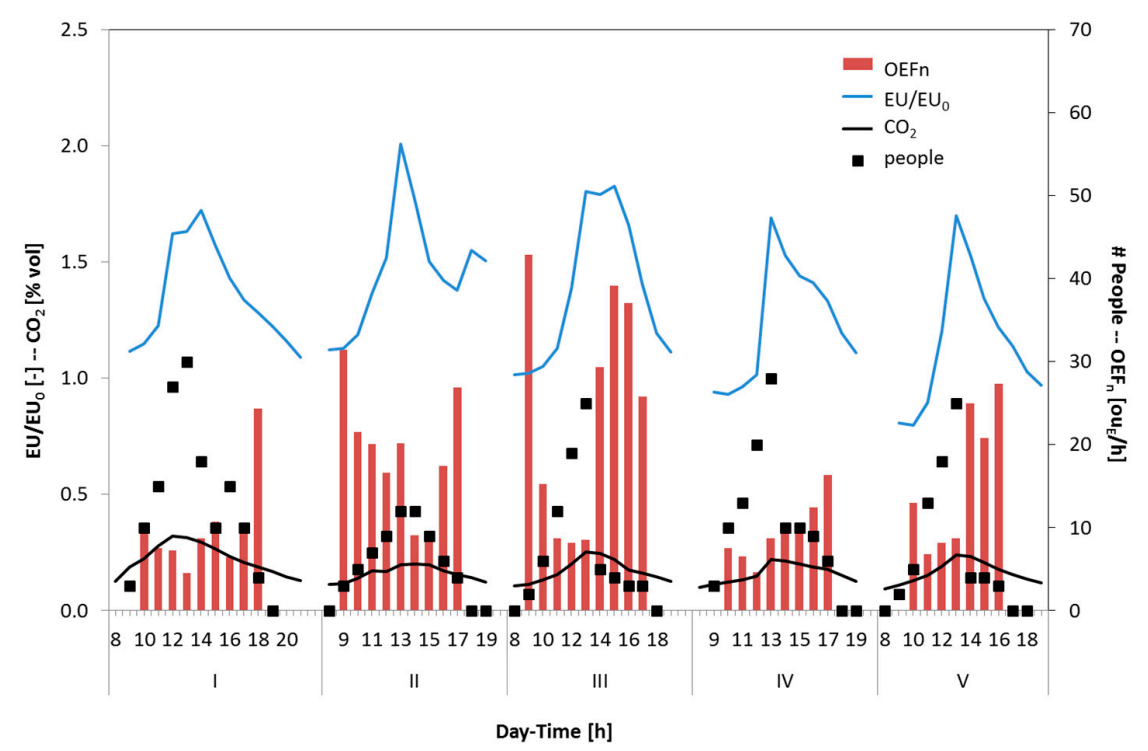

(a)

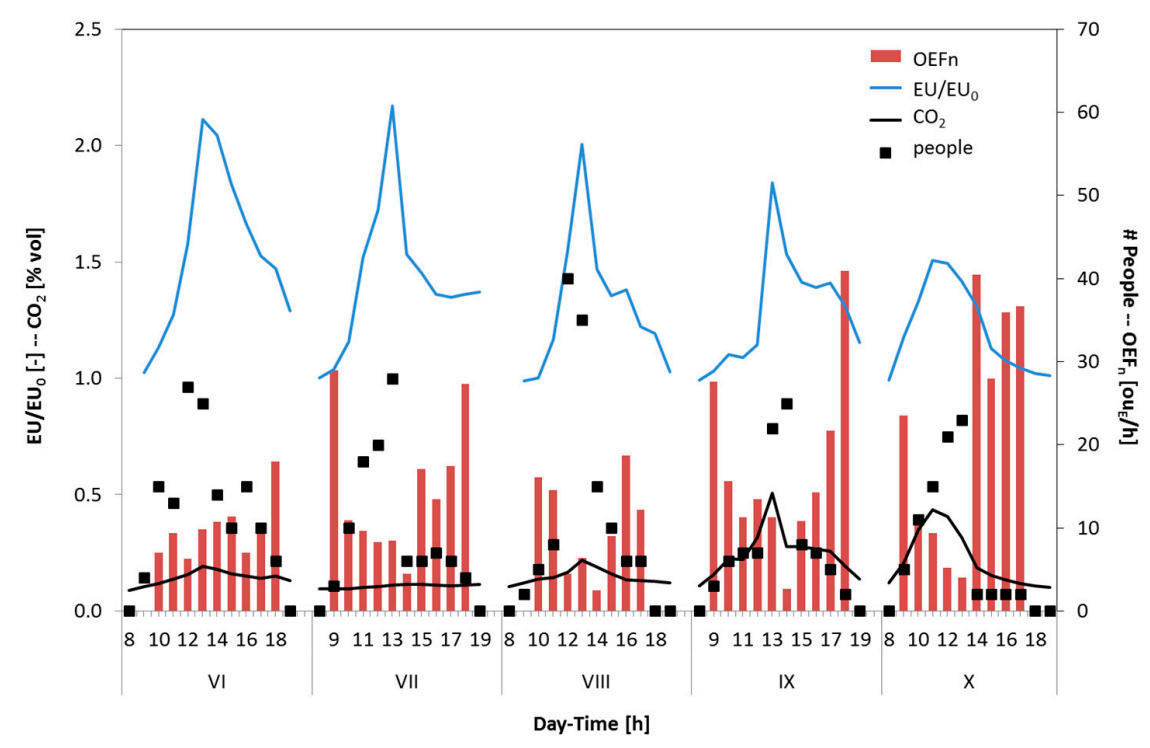

(b)

Figure 5. Trends of $\mathrm{EU} / \mathrm{EU}_{0}, \mathrm{CO}_{2}$ concentration, number of occupants and estimated $\mathrm{OEF}_{\mathrm{n}}$ for the period from day I to $\mathrm{V}(\mathbf{a})$; and for the period from day VI to $\mathrm{X}(\mathbf{b})$. 


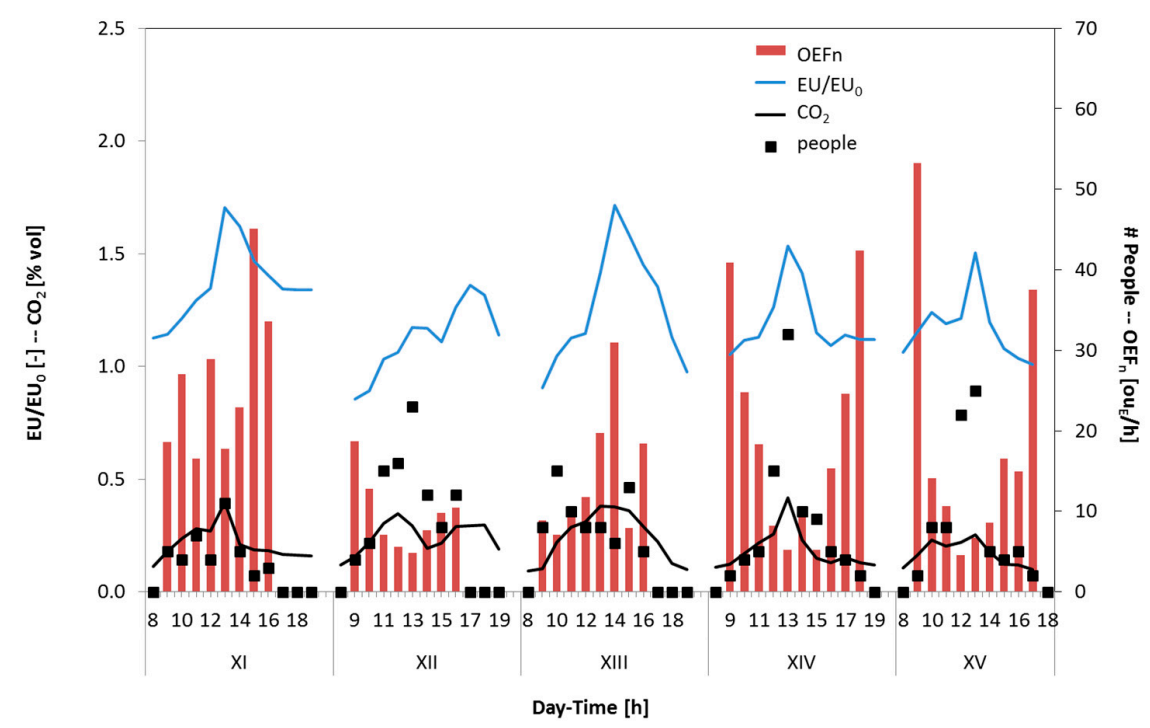

(a)

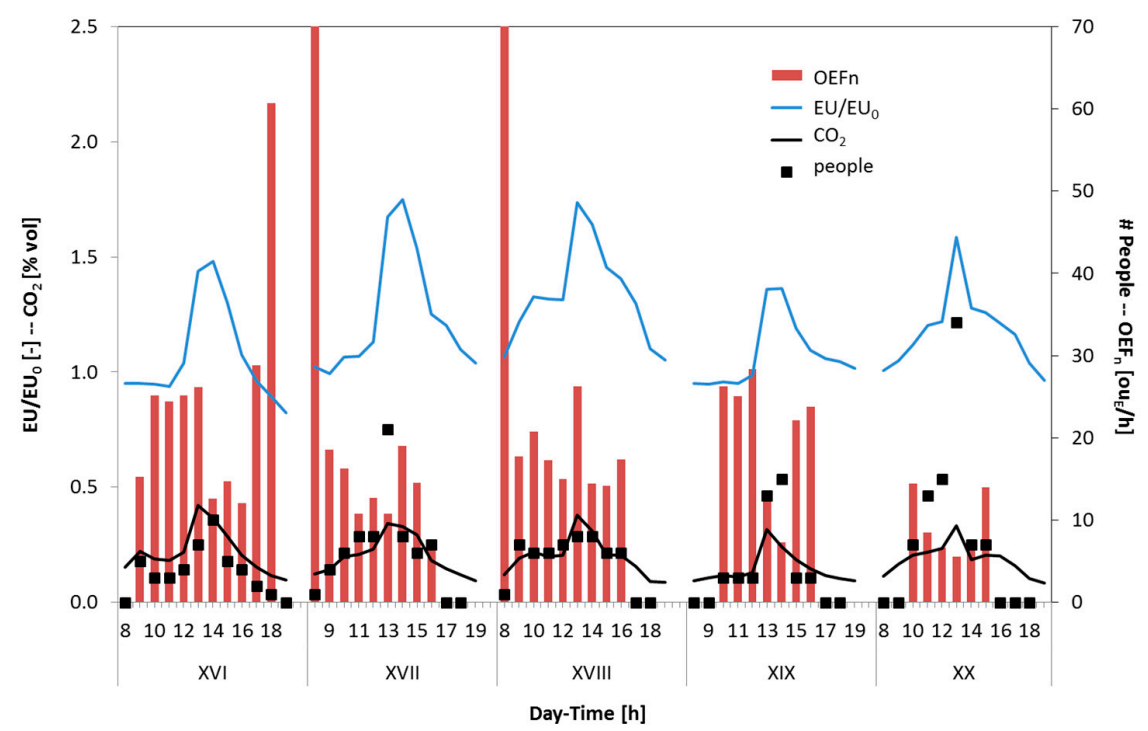

(b)

Figure 6. Trends of $\mathrm{EU} / \mathrm{EU}_{0}, \mathrm{CO}_{2}$ concentration, number of occupants and estimated $\mathrm{OEF}_{\mathrm{n}}$ for the period from day XI to XV (a); and for the period from day XVI to XX (b).

In most of the days considered, calculating the average OEF normalized by the number of people present in the room (i.e., OEFn), it is possible to observe an increase of the OEFn values during the late afternoon and the evening when the number of people decreases. This effect cannot be ascribed to the activity carried out by people (i.e., study) but to the presence of other sources and to the accumulation of odour in the room during the day. This can be due to the fact that the molecules of odour generally are larger/heavier than $\mathrm{CO}_{2}$ and $\mathrm{CO}$ molecules. More in detail, it can be assumed that the odorous emissions produced by the students' activities are mainly constituted by fatty acids, aldehydes and/or ketones. The molecular weight of these molecules and their steric hindrance, generally, are higher than those of $\mathrm{CO}_{2}$ or $\mathrm{CO}$ molecules. As a consequence, they require more time to diffuse and to mix with air; thus, a higher time is needed to remove the odour from the room, especially if the air exchange rate cannot be regulated by a mechanical ventilation system. This could be the cause of the high OEFn, often not associated to a corresponding increase of the $\mathrm{EU} / \mathrm{EU}_{0}$ values, estimated in particular in the 
post meridian period. This evidence highlights the importance to have forced air changes to better ensure the proper indoor air quality.

In Figure $6 \mathrm{~b}$ (i.e., days XVII and XVIII), it is possible to observe high OEFn at 8:00 a.m. when the number of people in the room is equal to one. These results cannot be only attributed to the background odour of the room due to furniture but also to the cleaning activity. Indeed, in the morning, between the 7:00 a.m. and 8:30 a.m., the cleaning of the study room was scheduled. The electronic nose has detected the cleaning activity (i.e., OEFn), especially when the cleaning operations are in proximity to the 8:00 a.m., as evidenced in a preliminary study performed by Sironi et al. [64]. Instead, the $\mathrm{CO}_{2}$ concentration remains low. The first hours of the day, showing an increase of OEFn due to the cleaning activity, were not taken into account because this aspect was not in the scope of the work.

For comparison purposes, an attempt to extend the modeling approach used for the evaluation of the $\mathrm{CO}_{2}$ trends was made to also model odour trends; in this case, the main problems are related to the fact that it is difficult to identify the odour sources and to properly define their emission rates (often not constant) in a complex environment like a study room; moreover, about the odours, there could be some sink effects or secondary reactions that could change the odour distribution within the room because their indoor levels are not solely a function of the sources and the air exchanges.

Therefore, an average value of OEFn was defined on the basis of the specific odour emission factors determined during the experimental campaign; then, considering the number of occupants and the AER previously estimated for the $\mathrm{CO}_{2}$ trends, the EU/EU $\mathrm{EU}_{0}$ profiles were predicted for the investigated period; some results are summarized in Figure 7. The model correctly predicts the rise-decay profiles observed experimentally, but there is no quantitative agreement between measured and predicted $\mathrm{EU} / \mathrm{EU}_{0}$ values. This confirms that, even in a study room, the odour is not related only to people present in this well-defined environment, but a more specific approach is required to correctly identify odour sources and the dynamics of the odour emission trends. As it can be seen from the parity plots of Figure 8, while it is possible to define a reasonable relationship between the occupants and the $\mathrm{CO}_{2}$ levels, a more complex situation was evidenced by odour emissions. In particular, in Figure 8, the predicted values of both $\mathrm{CO}_{2}$ and $\mathrm{EU} / \mathrm{EU}_{0}$ were compared with the $\mathrm{CO}_{2}$ and $\mathrm{EU} / \mathrm{EU}_{0}$ values measured during the whole experimental campaign. In these plots, the central solid line represents the ideal values (where experimental results and model predictions fully agree), while dashed lines and dotted lines represent a deviation of $\pm 50 \%$ and $\pm 30 \%$ from the ideal values. It can be noticed that most of the $\mathrm{CO}_{2}$ data are dispersed around the ideal line in the $\pm 30 \%$ area; this highlights that the proposed well-mixed room (WMR) model is able to reasonably predict the influence of the room occupants on this pollutant trends; on the other hand, $\mathrm{EU} / \mathrm{EU}_{0}$ values are clearly overestimated by the model (blue diamonds symbols, right side of Figure 8). The presence of people inside the room surely have an impact on the odour levels, but this contribution seem to have only a small influence on the overall $\mathrm{EU} / \mathrm{EU}_{0}$ trend. An attempt was made to define the relevance of this contribution and the results are represented by the red circle symbols of Figure 8; this data are well distributed around the ideal line, but, in this case, a reduced $\mathrm{OEF}_{n}$ value, equal to $20 \%$ of the average $\mathrm{OEF}_{\mathrm{n}}$ estimated from the experimental results of Figures 5 and 6, was used for the model calculation, thus confirming that other relevant sources, partly independent from the people number, contribute to the definition of the average odour emission rates and, consequently, to determine the measured $\mathrm{EU} / \mathrm{EU}_{0}$ profiles. This means that odour emissions and trends are due to a complex combination of factors, and a detailed approach is required to control odour levels in indoor environments like the one considered in the present study.

These results show that a monitoring system based only on the $\mathrm{CO}_{2}$ measurement might not be enough to properly monitor the indoor air quality, demonstrating that there may be situations where odours can be perceived intensely while the $\mathrm{CO}_{2}$ levels remain low. Therefore, an electronic nose system could efficiently integrate the common systems used to regulate the ventilation of indoor environments, in order to allow a better control of indoor air quality. 


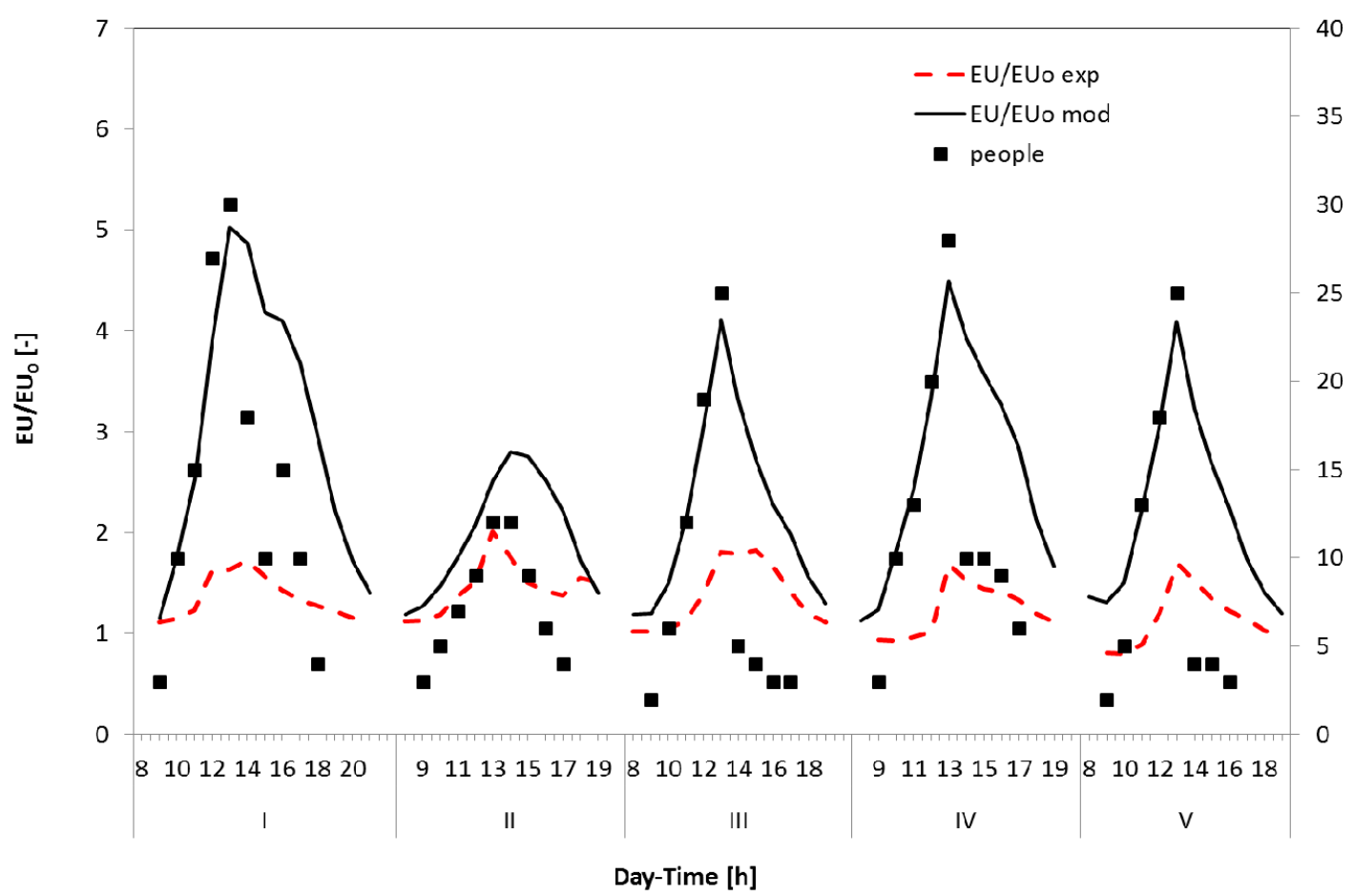

50

(a)

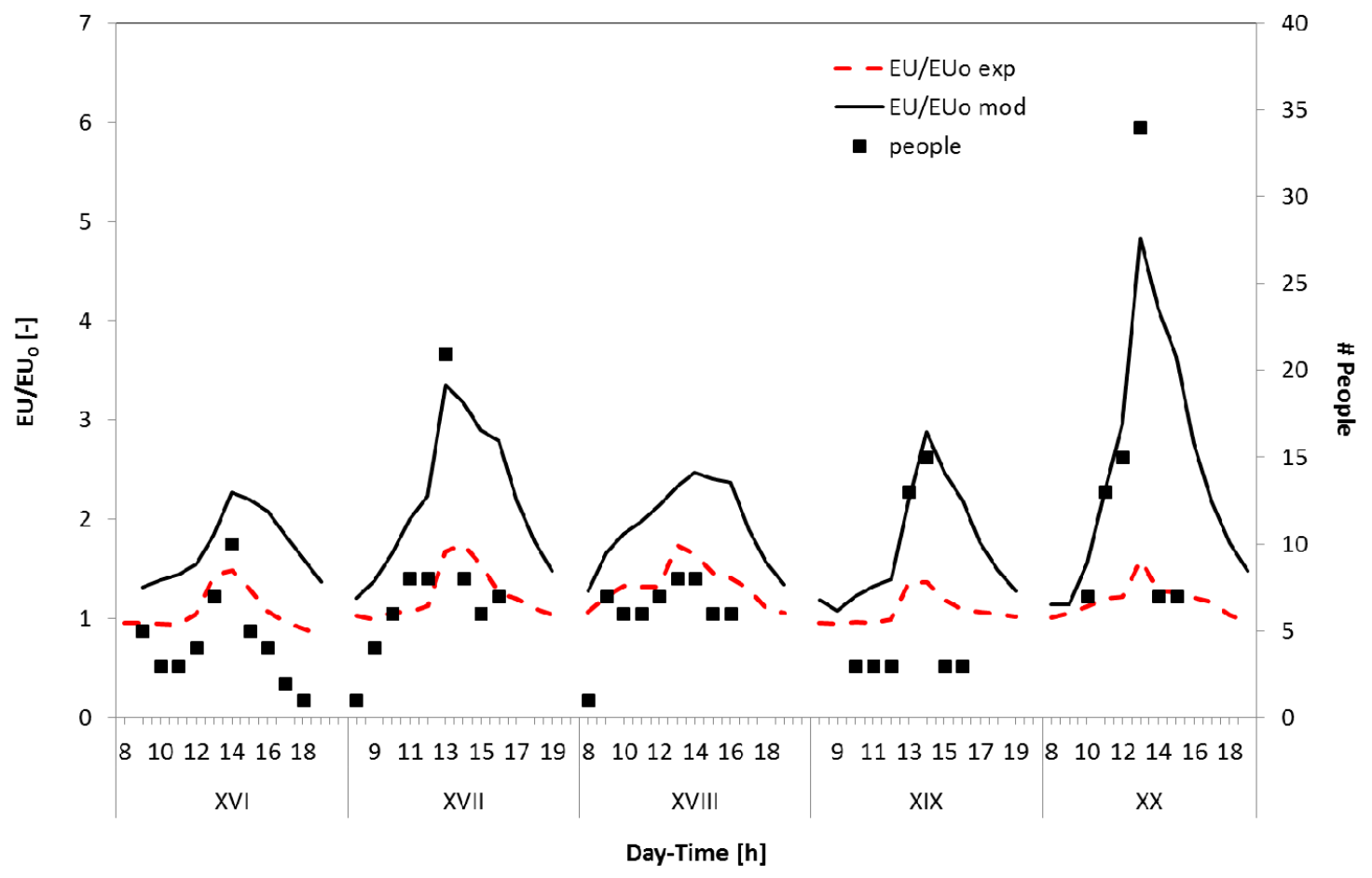

(b)

Figure 7. Experimental and predicted $\mathrm{EU} / \mathrm{EU}_{0}$ trends and number of occupants inside the naturally ventilated room investigated for the period from day I to V (a); and for the period from day XVI to XX (b). 


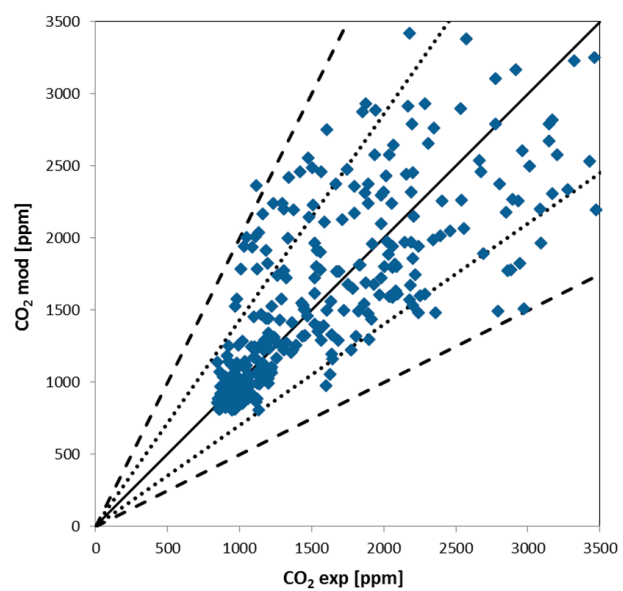

(a)

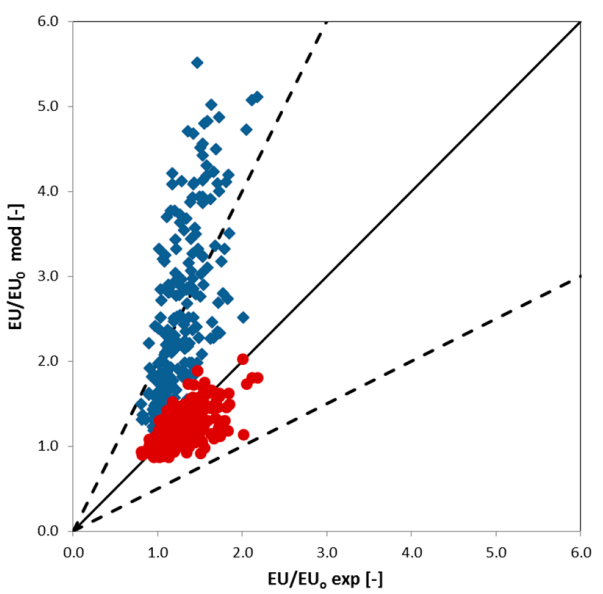

(b)

Figure 8. Parity plots of model predictions versus experimental observations for $\mathrm{CO}_{2}$ (a) and $\mathrm{EU} / \mathrm{EU}_{0}(\mathbf{b})$ found during the indoor monitoring campaign (blue diamonds symbols refer to predictions obtained with average $\mathrm{CO}_{2}$ and odour $\left(\mathrm{OEF}_{n}\right)$ emission rates estimated for the room occupants, while red circle symbols represent the predictions obtained considering only a $20 \%$ contribution of the room occupants to the odour emission trends).

\section{Conclusions}

The case study reported in this work presents an innovative method to evaluate the indoor air quality. Two different techniques have been combined to monitor a university room: a photoacustic multi-gas analyzer to detect the $\mathrm{CO}_{2}$ and an e-nose to detect odour trends. The work focuses the attention not only on $\mathrm{CO}_{2}$ concentration and on odour trends (i.e., $\mathrm{EU}_{\mathrm{i}}$ ) but also tried to determine the odour emission factors (OEFs) emitted by human activity.

The OEFs are not only descriptive indicators, but they also have a predictive function, in agreement with the research performed in the environmental field that brought about the development of OEFs for different kinds of industrial plants such as waste water treatment plants, animal rendering plants, landfills, etc.

In the present study, OEFs have been developed in order to assess the odour emissivity due to indoor human activities (i.e., studying and eating). The development of such OEFs is of practical interest because they can be used in the design of new mechanical ventilation systems for indoor environments.

The $\mathrm{CO}_{2}$ trends evaluated are typical of a naturally ventilated room, where the daily activities promote both the mixing of the air and the pollutants and the air exchanges with the external environments. A reasonable qualitative and quantitative agreement between the $\mathrm{CO}_{2}$ measurements and model predictions were obtained using an AER equal to 0.43 .

The electronic nose and photoacoustic multi-gas analyzer for the $\mathrm{CO}_{2}$ provide complementary information. In some of the days monitored, the e-nose detects odour molecules when the $\mathrm{CO}_{2}$ level was low. Moreover, in most of the monitored days, an increase of the odour emissions during the late afternoon and the evening was observed when the number of people decreases. This effect was not due to the activity carried out by the people (i.e., study) but to the accumulation of odour in the room during the day. The molecules of odour generally are larger/heavier than $\mathrm{CO}_{2}$ and $\mathrm{CO}$ molecules; as a consequence, more time is needed to remove the odour from the room. This evidence highlights the importance of having forced air changes to better ensure the indoor air quality.

These results show that a monitoring system based only on the $\mathrm{CO}_{2}$ measurement may not be enough to properly monitor the indoor air quality, demonstrating that there might be situations where odours can be perceived intensely while the $\mathrm{CO}_{2}$ levels remain low. Therefore, a small and cheap e-nose system represents an important addition to common systems for the regulation of the mechanical ventilation, based solely on temperature and $\mathrm{CO}_{2}$ measurement, in order to allow for an effective 
control of indoor air quality. Indeed, this study highlights that an e-nose can give supplementary information for the air quality monitoring by detecting odours that are derived from the activities carried out into typical indoor environments.

Author Contributions: Selena Sironi, Marco Derudi and Giuseppe Nano conceived, designed the experiments and supervised the work; Lidia Eusebio performed the experiments; Lidia Eusebio and Marco Derudi analyzed the data; and Lidia Eusebio, Marco Derudi, and Selena Sironi wrote the paper. Laura Capelli reviewed the manuscript.

Conflicts of Interest: The authors declare no conflict of interest.

\section{References}

1. Loutfi, A.; Coradeschi, S. Odor Recognition for Intelligent Systems. IEEE Intell. Syst. 2008, 23, 41-48. [CrossRef]

2. Pearce, T.C.; Schiffman, S.S.; Nagle, H.T.; Gardner, J.W. Handbook of Machine Olfaction: Electronic Nose Technology; Wiley-VCH Verlag GmbH \& Co.: Weinheim, Germany, 2003.

3. Röck, F.; Barsan, N.; Weimar, U. Electronic Nose: Current Status and Future Trends. Chem. Rev. 2008, 108, 705-725. [CrossRef] [PubMed]

4. Ampuero, S.; Bosset, J.O. The electronic nose applied to dairy products: A review. Sens. Actuators B Chem. 2003, 94, 1-12. [CrossRef]

5. Loutfi, A.; Coradeschi, S.; Mani, G.K.; Shankar, P.; Rayappan, J.B.B. Electronic noses for food quality: A review. J. Food Eng. 2015, 144, 103-111. [CrossRef]

6. Schaller, E.; Bosset, J.O.; Escher, F. “Electronic noses” and their application to food. Food Sci. Technol. 1998, 31, 305-316. [CrossRef]

7. Baietto, M.; Wilson, A.D. Electronic-Nose Applications for Fruit Identification, Ripeness and Quality Grading. Sensors 2015, 15, 899-931. [CrossRef] [PubMed]

8. Peris, M.; Escuder-Gilabert, L. A 21st century technique for food control: Electronic noses. Anal. Chim. Acta 2009, 638, 1-15. [CrossRef] [PubMed]

9. Dymerski, T.; Gẹbicki, J.; Wardencki, W.; Namieśnik, J. Quality evaluation of agricultural distillates using an electronic nose. Sensors 2013, 13, 15954-15967. [CrossRef] [PubMed]

10. Dymerski, T.; Gębicki, J.; Wardencki, W.; Namieśnik, J. Application of an electronic nose instrument to fast classification of polish honey types. Sensors 2014, 14, 10709-10724. [CrossRef] [PubMed]

11. Roda, B.; Mirasoli, M.; Zattoni, A.; Casale, M.; Oliveri, P.; Bigi, A.; Reschiglian, P.; Simoni, P.; Roda, A. A new analytical platform based on field-flow fractionation and olfactory sensor to improve the detection of viable and non-viable bacteria in food. Anal. Bioanal. Chem. 2016, 408, 7367-7377. [CrossRef] [PubMed]

12. Buratti, S.; Benedetti, S.; Giovanelli, G. Application of electronic senses to characterize espresso coffees brewed with different thermal profiles. Eur. Food. Res. Technol. 2016. [CrossRef]

13. Melucci, D.; Bendini, A.; Tesini, F.; Barbieri, S.; Zappi, A.; Vichi, S.; Conte, L.; Gallina Toschi, T. Rapid direct analysis to discriminate geographic origin of extra virgin olive oils by flash gas chromatography electronic nose and chemometrics. Food Chem. 2016, 204, 263-273. [CrossRef] [PubMed]

14. Cagnasso, S.; Falasconi, M.; Previdi, M.P.; Franceschini, B.; Cavalieri, C.; Sberveglieri, V.; Rovere, P. Rapid Screening of Alicyclobacillus acidoterrestris Spoilage of Fruit Juices by Electronic Nose: A Confirmation Study. J. Sens. 2010, 2010, 143173. [CrossRef]

15. Falasconi, M.; Concina, I.; Gobbi, E.; Sberveglieri, V.; Pulvirenti, A.; Sberveglieri, G. Electronic nose for microbiological quality control of food products. Int. J. Electrochem. 2012, 2012, 715763. [CrossRef]

16. Ponzoni, A.; Comini, E.; Concina, I.; Ferroni, M.; Falasconi, M.; Gobbi, E.; Sberveglieri, V.; Sberveglieri, G. Nanostructured metal oxide gas sensors, application in security and food quality fields. Sensors 2012, 12, 17023-17045. [CrossRef] [PubMed]

17. Longobardi, F.; Casiello, G.; Ventrella, A.; Mazzilli, V.; Nardelli, A.; Sacco, D.; Catucci, L.; Agostiano, A. Electronic nose and isotope ratio mass spectrometry in combination with chemometrics for the characterization of the geographical origin of Italian sweet cherries. Food Chem. 2015, 170, 90-96. [CrossRef] [PubMed]

18. Sberveglieri, V.; Carmona, E.N.; Comini, E.; Ponzoni, A.; Zappa, D.; Pirrotta, O.; Pulvirenti, A. A Novel Electronic Nose as Adaptable Device to Judge Microbiological Quality and Safety in Foodstuff. Biomed. Res. Int. 2014, 2014, 1-6. [CrossRef] [PubMed] 
19. Cellini, A.; Biondi, E.; Blasioli, S.; Rocchi, L.; Farneti, B.; Braschi, I.; Savioli, S.; Rodriguez-Estrada, M.T.; Biasioli, F.; Spinelli, F. Early detection of bacterial diseases in apple plants by analysis of volatile organic compounds profiles and use of electronic nose. Ann. Appl. Biol. 2016, 168, 409-420. [CrossRef]

20. Dubreuil, B.; Bonnefille, M.; Neitz, S.; Talou, T. Prospective Experiments of e-Nose for Cosmetics Applications: Recognition of Sweat Odors. In Artificial Chemical Sensing: Olfaction and the Electronic Nose (ISOEN 2001), Proceedings of the Eighth International Symposium, Washington, DC, 20-24 March 2001; The Electrochemical Society: Pennington, NJ, USA, 2001.

21. Baldwin, E.A.; Bai, J.; Plotto, A.; Dea, S. Electronic noses and tongues applications for the food and pharmaceutical industries. Sensors 2011, 11, 4744-4766. [CrossRef] [PubMed]

22. Capelli, L.; Taverna, G.; Bellini, A.; Eusebio, L.; Buffi, N.; Lazzeri, M.; Guazzoni, G.; Bozzini, G.; Seveso, M.; Mandressi, A.; et al. Application and Uses of Electronic Noses for Clinical Diagnosis on Urine Samples: A Review. Sensors 2016, 16, 1708. [CrossRef] [PubMed]

23. Persaud, K.C. Medical applications of odor-sensing devices. Int. J. Low. Extrem. Wounds 2005, 4, 50-56. [CrossRef] [PubMed]

24. Wilson, A.D.; Baietto, M. Advances in Electronic-Nose Technologies Developed for Biomedical Applications. Sensors 2011, 11, 1105-1176. [CrossRef] [PubMed]

25. Oh, E.H.; Song, H.S.; Park, T.H. Recent advances in electronic and bioelectronics noses and their biomedical applications. Enzyme Microb. Technol. 2011, 48, 427-437. [CrossRef] [PubMed]

26. Wilson, A.D. Advances in Electronic-Nose Technologies for the Detection of Volatile Biomarker Metabolites in the Human Breath. Metabolites 2015, 5, 140-163. [CrossRef] [PubMed]

27. Mantini, A.; Di Natale, C.; Macagnano, A.; Paolesse, R.; Finazzi-Agrò, A.; D’Amico, A. Biomedical application of an electronic nose. Crit. Rev. Biomed. Eng. 2000, 28, 481-485. [CrossRef] [PubMed]

28. D’Amico, A.; Di Natale, C.; Paolesse, R.; Macagnano, A.; Martinelli, E.; Pennazza, G.; Santonico, M.; Bernabei, M.; Roscioni, C.; Galluccio, G.; et al. Olfactory systems for medical applications. Sens. Actuators $B$ Chem. 2008, 130, 458-465. [CrossRef]

29. Casalinuovo, I.A.; Di Pierro, D.; Coletta, M.; Di Francesco, P. Application of electronic noses for disease diagnosis and food spoilage detection. Sensors 2006, 6, 1428-1439. [CrossRef]

30. Di Natale, C.; Mantini, A.; Maccagnano, A.; Antuzzi, D.; Paolesse, R.; D’Amico, A. Electronic nose analysis of urine samples containing blood. Physiol. Meas. 1999, 20, 377-384. [CrossRef] [PubMed]

31. Di Natale, C.; Maccagnano, A.; Martinelli, E.; Paolesse, R.; D’Arcangelo, G.; Roscioni, C.; Finazzi-Agrò, A.; D'Amico, A. Lung cancer identification by the analysis of breath by means of an array of non-selective gas sensors. Biosens. Bioelectron. 2003, 18, 1209-1218. [CrossRef]

32. Bruno, E.; Alessandrini, M.; Ottaviani, F.; Delfini, A.; Di Pierro, D.; Camillo, A.; De Lorenzo, A. Can the electronic nose diagnose chronic rhinosinusitis? A new experimental study. Eur. Arch. Otorhinolaryngol. 2008, 265, 425-428. [CrossRef] [PubMed]

33. Romain, A.C.; Nicolas, J. Long term stability of metal oxide-based gas sensors for e-nose environmental applications: An overview. Sens. Actuators B Chem. 2010, 146, 502-506. [CrossRef]

34. Bourgeois, W.; Romain, A.C.; Nicolas, J.; Stuetz, R.M. The use of sensor arrays for environmental monitoring: Interests and limitations. J. Environ. Monitor. 2003, 5, 852-860. [CrossRef]

35. Deshmukh, S.; Bandyopadhyay, R.; Bhattacharyya, N.; Pandey, R.A.; Jana, A. Application of electronic nose for industrial odors and gaseous emissions measurement and monitoring-An overview. Talanta 2015, 144, 329-340. [CrossRef] [PubMed]

36. Capelli, L.; Sironi, S.; Del Rosso, R. Electronic Noses for Environmental Monitoring Applications. Sensors 2014, 14, 19979-20007. [CrossRef] [PubMed]

37. Wilson, A.D. Diverse Applications of Electronic-Nose Technologies in Agriculture and Forestry. Sensors 2013, 13, 2295-2348. [CrossRef] [PubMed]

38. Wilson, A.D. Review of Electronic-nose Technologies and Algorithms to Detect Hazardous Chemicals in the Environment. Procedia Technol. 2012, 1, 453-463. [CrossRef]

39. Gebicki, J.; Byliński, H.; Namieśnik, J. Measurement techniques for assessing the olfactory impact of municipal sewage treatment plants. Environ. Monit. Assess. 2016, 188, 32. [CrossRef] [PubMed]

40. Gębicki, J.; Dymerski, T.; Namieśnik, J. Investigation of air quality beside a municipal landfill: The fate of malodour compounds as a model VOC. Environments 2017, 4, 7. [CrossRef] 
41. Eusebio, L.; Capelli, L.; Sironi, S. Electronic Nose Testing Procedure for the Definition of Minimum Performance Requirements for Environmental Odor Monitoring. Sensors 2016, 16, 1548. [CrossRef] [PubMed]

42. Eusebio, L.; Sironi, S.; Capelli, L.; Il Grande, M.; Della Torre, M. Continuous Evaluation of Odour Concentration at a Plant. Chem. Eng. Trans. 2014, 40, 133-138.

43. Micone, P.G.; Guy, C. Odour quantification by a sensor array: An application to landfill gas odours from two different municipal waste treatment works. Sens. Actuators B Chem. 2007, 120, 628-637. [CrossRef]

44. Capelli, L.; Sironi, S.; Centola, P.; del Rosso, R.; Il Grande, M. Electronic noses for the continuous monitoring of odours from a wastewater treatment plant at specific receptors: Focus on training methods. Sens. Actuators B Chem. 2008, 131, 53-62. [CrossRef]

45. Sironi, S.; Capelli, L.; Centola, P.; del Rosso, R.; Il Grande, M. Continuous monitoring of odours from a composting plant using electronic noses. Waste Manag. 2007, 27, 389-397. [CrossRef] [PubMed]

46. Dentoni, L.; Capelli, L.; Sironi, S.; Del Rosso, R.; Centola, P.; Della Torre, M.; Demattè, F. Development of an Electronic Nose for Environmental Monitoring: Detection of Specific Environmentally Important Gases at Their Odor Detection Threshold Concentration. In Proceedings of the AIP Conference Proceedings 14th International Symposium on Olfaction and Electronic Nose (ISOEN 2011), New York, NY, USA, $2-5$ May 2011; pp. 207-208.

47. Dentoni, L.; Capelli, L.; Sironi, S.; del Rosso, R.; Zanetti, S.; Della Torre, M. Development of an Electronic Nose for Environmental Odour Monitoring. Sensors 2012, 12, 14363-14381. [CrossRef] [PubMed]

48. Brattoli, M.; de Gennaro, G.; de Pinto, V.; Loiotile, A.D.; Lovascio, S.; Penza, M. Odour Detection Methods: Olfactometry and Chemical Sensors. Sensors 2011, 11, 5290-5322. [CrossRef] [PubMed]

49. Amodio, M.; Brattoli, M.; Dambruoso, P.; De Gennaro, L.; De Gennaro, G.; Loiotile, A.D.; Trizio, L. Odour impact assessment by a multiparametric system (electronic Noses/ch4-nmhc Analyser). Chem. Eng. Trans. 2012, 30, 199-204.

50. Penza, M.; Suriano, D.; Cassano, G.; Rossi, R.; Alvisi, M.; Pfister, V.; Trizio, L.; Brattoli, M.; De Gennaro, G. A gas sensor array for environmental air monitoring: A study case of application of artificial neural networks. AIP Conf. Proc. 2011, 1362, 205-206.

51. Mantovani, A.; Artoni, R.; Barausse, A.; Palmeri, L.; Pittarello, A.; Benzo, M. Modeling odour dispersion from composting plants: Comparison with Electronic Nose measurements. Chem. Eng. Trans. 2010, 23, $297-302$.

52. Giungato, P.; de Gennaro, G.; Barbieri, P.; Briguglio, S.; Amodio, M.; de Gennaro, L.; Lasigna, F. Improving recognition of odors in a waste management plant by using electronic noses with different technologies, gas chromatography-mass spectrometry/olfactometry and dynamic olfactometry. J. Clean. Prod. 2016, 133, 1395-1402. [CrossRef]

53. Arnold, C.; Harms, M.; Goschnick, J. Air quality monitoring and fire detection with the Karlsruhe Electronic Micronose KAMINA. IEEE Sens. J. 2002, 2, 179-188. [CrossRef]

54. Herberger, S.; Herold, M.; Ulmer, H.; Burdack-Freitag, A.; Mayer, F. Detection of human effluents by a MOS gas sensor in correlation to VOC quantification by GC/MS. Build. Environ. 2010, 45, 2430-2439. [CrossRef]

55. Batog, P.; Badura, M. Dynamic of Changes in Carbon Dioxide Concentration in Bedrooms. Procedia Eng. 2013, 57, 175-182. [CrossRef]

56. Bitter, F.; Muller, B.; Muller, D. Estimation of odour intensity of indoor air pollutants from building materials with a multi-gas sensor system. Build. Environ. 2010, 45, 197-204. [CrossRef]

57. Wolfrum, E.J.; Meglen, R.M.; Peterson, D.; Sluiter, J. Metal oxide sensor array for detection, differentiation and quantification of volatile organic compounds at sub-parts-per-million concentration levels. Sens. Actuators B Chem. 2006, 115, 322-329. [CrossRef]

58. Kuske, M.; Romain, A.-C.; Nicolas, J. Microbial volatile organic compound as indicators of fungi. Can an electronic nose detect fungi in indoor environments? Build. Environ. 2005, 40, 824-831. [CrossRef]

59. Tian, F.C.; Kadri, C.; Zhang, L.; Feng, J.W.; Juan, L.H.; Na, P.L. A novel cost-effective portable electronic nose for indoor/in-car air quality monitoring. In Proceedings of International Conference on Computer Distributed Control and Intelligent Environmental Monitoring, Zhangiajie, China, 5-6 March 2012; pp. 4-8.

60. Herberger, S.; Ulmer, H. Indoor Air Quality Monitoring Improving Air Quality Perception. Clean 2012, 40, 578-585. [CrossRef]

61. Kim, J.-H.; Chun, J.S.; Kim, J.W.; Choi, W.J.; Baik, J.M. Self-Powered, Room-Temperature Electronic Nose Based on Triboelectrifi cation and Heterogeneous Catalytic Reaction. Adv. Funct. Mater. 2015, 25, 7049-7055. [CrossRef] 
62. Burresi, A.; Fort, A.; Rocchi, S.; Serrano, B.; Ulivieri, N.; Vignoli, V. Dynamic CO recognition in presence of interfering gases by using one MOX sensor and a selected temperature profile. Sens. Actuators B 2005, 106, 40-43. [CrossRef]

63. Zampolli, S.; Elmi, I.; Ahmed, F.; Passini, M.; Cardinali, G.C.; Nicoletti, S.; Dori, L. An electronic nose based on solid state sensor arrays for low-cost indoor air quality monitoring applications. Sens. Actuators B 2004, 101, 39-46. [CrossRef]

64. Sironi, S.; Eusebio, L.; Capelli, L.; Remondini, M.; Del Rosso, R. Use of an electronic nose for indoor air quality monitoring. Chem. Eng. Trans. 2014, 40, 73-78.

65. Nozza, E.; Capelli, L.; Eusebio, L.; Derudi, M.; Nano, G.; Del Rosso, R.; Sironi, S. The role of bioethanol flueless fireplaces on indoor air quality: Focus on odour emissions. Build. Environ. 2016, 98, 98-106. [CrossRef]

66. ASHRAE 62.1-2004. In Ventilation for Acceptable Indoor Air Quality; American Society of Heating, Refrigeration and Air-Conditioning Engineers: Atlanta, GA, USA, 2004.

67. CEN, EN 13779: 2007. In Ventilation for Non-Residential Buildings_Performance Requirements for Ventilation and Room-Conditioning Systems; Comitée Européen de Normalisation: Brussels, Belgium, 2007.

68. CEN, EN 15251: 2008. In Indoor Environmental Input Parameters for Design and Assessment of Energy Performance of Buildings-Addressing Indoor Air Quality, Thermal Environment, Lighting and Acoustics; Comitée Européen de Normalisation: Brussels, Belgium, 2008.

69. DIN 1946-2: 1994-01. In Ventilation and Air Conditioning; Technical Health Requirements; Beuth Verlag GmbH: Berlin, Germany, 1994.

70. Lucernoni, F.; Tapparo, F.; Capelli, L.; Sironi, S. Evaluation of an Odour Emission Factor (OEF) to estimate odour emissions from landfill surfaces. Atmos. Environ. 2016, 144, 87-99. [CrossRef]

71. Lucernoni, F.; Capelli, L.; Sironi, S. Comparison of different approaches for the estimation of odour emissions from landfill surfaces. Waste Manag. 2016. [CrossRef] [PubMed]

72. Capelli, L.; Sironi, S.; Del Rosso, R.; Céntola, P. Predicting odour emissions from wastewater treatment plants by means of odour emission factors. Water Res. 2009, 43, 1977-1985. [CrossRef] [PubMed]

73. Capelli, L.; Sironi, S.; Del Rosso, R. Odour emission factors: Fundamental tools for air quality management. Chem. Eng. Trans. 2014, 40, 193-198.

74. Sironi, S.; Capelli, L.; Céntola, P.; Del Rosso, R.; Il Grande, M. Odour emission factors for assessment and prediction of Italian MSW landfills odour impact. Atmos. Environ. 2005, 39, 5387-5394. [CrossRef]

75. Capelli, L.; Sironi, S.; Del Rosso, R.; Magnano, E. Evaluation of landfill surface emissions. Chem. Eng. Trans. 2014, 40, 187-192.

76. Mielcarek, P.; Rzeźnik, W. Odor emission factors from livestock production. Pol. J. Environ. Stud. 2015, 24, 27-35. [CrossRef]

77. Sironi, S.; Capelli, L.; Céntola, P.; Del Rosso, R.; Il Grande, M. Odour emission factors for assessment and prediction of Italian rendering plants odour impact. Chem. Eng. Trans. 2007, 131, 225-231. [CrossRef]

78. Penman, J.M. An experimental determination of ventilation rate in occupied rooms using atmospheric carbon dioxide concentration. Build. Environ. 1980, 15, 45-47. [CrossRef]

79. Lu, T.; Knuutila, A.; Viljanen, M.; Lu, X. A novel methodology for estimating space air change rates and occupant $\mathrm{CO}_{2}$ generation rates from measurements in mechanically-ventilated buildings. Build. Environ. 2010, 45, 1161-1172. [CrossRef]

80. Mahyuddin, N.; Awbi, H. The spatial distribution of carbon dioxide in an environmental test chamber. Build. Environ. 2010, 45, 1993-2001. [CrossRef]

81. Woodcock, R.C. $\mathrm{CO}_{2}$ measurements for IAQ analysis. Occup. Health Saf. 2000, 69, 56-58. [PubMed]

82. Derudi, M.; Gelosa, S.; Sliepcevich, A.; Cattaneo, A.; Rota, R.; Cavallo, D.; Nano, G. Emissions of air pollutants from scented candles burning in a test chamber. Atmos. Environ. 2012, 55, 257-262. [CrossRef]

83. Derudi, M.; Gelosa, S.; Sliepcevich, A.; Cattaneo, A.; Cavallo, D.; Rota, R.; Nano, G. Emission of air pollutants from burning candles with different composition in indoor environments. Environ. Sci. Pollut. Res. 2014, 21, 4320-4330. [CrossRef] [PubMed]

(C) 2017 by the authors. Licensee MDPI, Basel, Switzerland. This article is an open access article distributed under the terms and conditions of the Creative Commons Attribution (CC BY) license (http:/ / creativecommons.org/licenses/by/4.0/). 